\title{
Tunceli Dağ Sarımsağının (Allium tuncelianum) Rat Kalp Dokusu Antioksidan Enzim Düzeylerine Etkisi ve Fenolik Bileşenlerinin Karakterizasyonu
}

Türkan KUTLU1 ${ }^{\circ}$ iD , Kasım TAKIM ${ }^{2}$ iD , Merve Gökşin KARAASLAN1 ${ }^{\text {(D) }}$, Mustafa Abdullah YILMAZ3

1 İnönü Üniversitesi, Fen-Edebiyat Fakültesi, Kimya Bölümü,44280, Malatya, ${ }^{2}$ Harran Üniversitesi Veteriner Fakültesi, Veteriner Hekimliği Temel Bilimleri Bölümü, Şanlıurfa, ${ }^{3}$ Dicle Üniversitesi , Eczacılık Fakültesi, Farmasötik Kimya Anabilim Dalı, Diyarbakır 凶: kasimtakim@hotmail.com

\section{ÖZET}

Bu çalışmada, Allium tuncelianum'un su ekstraktlarının, fenolik bileşikleri LC-MS/MS ve HPLC ile belirlenmiştir. Antioksidan enzim düzeylerine etkisini belirlemek için Wistar albino tipi dişi sıçanlar kullanılmıştır. Her grupta 8 adet $(n=8)$ hayvan içeren 5 grup oluşturuldu. Birinci grup kontrol, ikinci grup 7,12 Dimethylbenz[a]anthracene (DMBA), üçüncü ve dördüncü grup DMBA + 250 ve $500 \mathrm{mg} / \mathrm{kg} /$ gün A.tuncelianum, beşinci grup DMBA + $200 \mathrm{mg} / \mathrm{kg}$ E vitamini (haftada iki kez) verilmiştir. Deney hayvanları bir ay süresince beslenmiş ve dekapite edilerek kalp dokusu alınmıştır. Allium tuncelianum'un su ekstraktının kalp dokusu üzerine antioksidan ve oksidatif stres markırı olan; katalaz (CAT) ve süpeoksit dismutaz (SOD), malondialdehit (MDA) ve total glutatyon (GSH) parametreleri incelenmiştir. Bu çalışma sonucunda Allium tuncelianum'un su ekstraktının fenolik bileşik çeşitliliği açısından fakir ancak diğer bazı bileşenler (pirokatekol, kainik asit, fumarik asit ve malik asit) açısından oldukça zengin bir içeriğe sahip olduğu bulunmuştur. Kalp dokusunda antioksidan enzim (CAT, SOD) düzeylerinin oksidatif stres oluşturulan gruplarda, kontrol gruplarına göre anlamlı bir şekilde $(\mathrm{p}<0.05)$ azaldığı belirlenmiştir. Allium tuncelianum ekstreleri verilen gruplarda; CAT enzim aktivitesinde istatiksel olarak anlamlı $(\mathrm{p}<0.05)$ azalma, SOD enzim aktivitesinde 7,12-DMBA verilen gruba göre istatiksel olarak anlamlı $(\mathrm{p}<0.05)$ artma gözlenmiştir. Ayrıca 7,12-DMBA verilen gruba göre MDA düzeylerinde istatiksel olarak anlamlı $(\mathrm{p}<0.05)$ azalma görülmüştür. Bu sonuçlar; Allium tuncelianum'un su ekstraktlarının, SOD enzim aktivitesini artırarak ve MDA düzeyini azaltarak oksidatif stresi önleyebileceğini göstermektedir.
DOI:10.18016/ ksudobil.397023

\section{Makale Tarihçesi}

Geliş Tarihi : 20.02.2018

Kabul Tarihi : 06.04.2018

Anahtar Kelimeler

Tunceli Dağ Sarımsağı, LC-MS/MS,

Fenolik,

Antioksidan Enzim

\section{Araştırma Makalesi}

\section{Article History}

Received : 20.02.2018

Accepted : 06.04.2018

extracts were determined by LC-MS / MS and HPLC. Wistar albino female rats were used to determine the effect on antioxidant enzyme levels. Five groups of female rats, each containing eight individuals were studied. The first group was control without any treatments. The second group was treated 7,12-DMBA, third, and fourth groups were treated with DMBA +250 , and $500 \mathrm{mg} / \mathrm{kg} /$ day of Allium tuncelianum water extracts, fifth group was treated DMBA+ $200 \mathrm{mg} / \mathrm{kg}$ of $\mathrm{E}$ vitamin (twice a week) for one month, respectively. The rats were feed for one month, slaughtered afterwards and the cardiac tissue was taken for the experiments. Catalase (CAT) and superoxide dismutase (SOD), Malondialdehide (MDA) and Glutatyon (GSH) parameters, which are antioxidant and oxidative stress markers on the heart tissue of Allium tuncelianum water extract were investigated. Result of this study indicated that Allium tuncelianum water extract was poor in phenolic compound diversity but had a very rich content in terms of some other components including pyrocatechol, kainic acid,

\author{
Keywords \\ Tunceli Mountain Garlic, \\ LC-MS / MS, \\ Phenolic, \\ Antioxidant Enzyme
}

\section{Research Article}


fumaric acid and malic acid. Antioxidant enzymes (CAT, SOD) levels in heart tissue decreased significantly $(\mathrm{p}<0.05)$ in the oxidative stress groups compared to the control groups $(p<0.05)$ and Allium tuncelianum water extract showed a decrease in CAT enzyme activity and an increase in SOD enzyme activity relative to the group given 7,12 -DMBA. There was also a decrease in MDA levels compared to the 7,12 -DMBA group. It can be concluded that Allium tuncelianum water extract can prevent oxidative stress by increasing SOD enzyme activity and reducing MDA levels.

To cite: Kutlu T, Takım K, Karaaslan MG, Yılmaz, MA 2018. Tunceli Dağ Sarımsağının (Allium tuncelianum) Rat Kalp Dokusu Antioksidan Enzim Düzeylerine Etkisi ve Fenolik Bileşenlerinin Karakterizasyonu. KSÜ Tarım ve Doğa Derg 21(5): 632-643. DOI:10.18016/ksudobil.397023.

\section{GİRIŞ}

Doğa ve insan müthiş bir uyum içerisinde bulunmaktadır. Nitekim insan ihtiyacı olan herşeyi eksiksiz bir şekilde doğada bulagelmiş ve halende bulmaya devam etmektedir. Dolayısıyla doğada bulanan fitoterapotik ajanı birtakım bitkiler özelliklede son zamanlarda bilim dünyasında da bir hayli ilgi görmüş ve üzerinde pek çok bilimsel araştırma yapılmıştır. Sarımsak (Allium sativum L.), Liliaceae familyasına ait bir bitki türüdür ve yaklaşık 3000 yıldır pek çok uygarlık tarafindan hastalıkların tedavisinde, kullanılmaktadır. Türkiye Allium türleri yönünden zengin bir ülkedir. Dünyada 750 kadar Allium türü bulunmakta, bunların yaklaşı 170 tanesine Türkiye'de rastlanmaktadır. Ülkemizdeki Allium türlerinin yaklaşık \% 40 ' $\mathrm{mm}$ endemik olduğu belirtilmektedir (Evans ve ark., 1997). Tunceli sarımsağ tuncelianum (A. tuncelianum), endemik bir bitki türü olup, Tunceli ili ve çevresinde ve özellikle Ovacık çevresinde yaygın olarak bulunmaktadır. Tunceli sarımsağı ve Ovacık sarımsağı adı altında satı̧̧ı yapılmakta ve ticari ürün olarak kullanılmaktadır (Takım, 2015).

Reaktif oksijen türleri organizmanin yapisal ve fonksiyonel biyomoleküllerini etkileyerek oksidatif stress oluşturur. Oksidatif stres altındaki biomoleküller okside olarak fonksiyonel bozulmaya uğrarlar. Antioksidanlar, hücrelere zarar veren reaktif oksijen ve azot türlerini, etkin bir şekilde indirgeyerek düşük toksisiteli veya toksik olmayan ürünlere dönüştürürler. Organizmalarda bulunan bu zararlı bileşiklerin varlığı, sağlıklı bir yaşam için antioksidanları hayatın vazgeçilmez bir parçası haline getirmektedir (Geleijnse ve ark., 1999). Üzerinde dünyada en çok çalışma yapılan bitkisel ürünler arasında olan sarımsak (Allium sativum L.), insan beslenmesi yönünden önemli olan birçok vitamin ve mineral maddesi içermesinin yanında, önemli bir tıbbi bitki olup bakterisidal, hipoglisemik, antimutajenik ve antikanserojenik özellikleri nedeni ile, pek çok hastalığın tedavisinde kullanılmaktadır. Sarımsakta çok sayıda değişik fitokimyasal bileşikler vardır. Sarımsağın antioksidatif özellikleri içerdiği kükürtlü bileşiklerden ve fenolik bileşenlerden kaynaklandığ (Martins ve ark., 2016).
Dimetilbenz[a]ntrasen (DMBA) metabolizması sırasında hücre içerisinde reaktif oksijen türleri (ROT) üretir. ROT hücre içerisinde üretildiği yerden diğer sağlam hücrelere yayılabilir. Böylece oluşan ROT'un lipit peroksidasyonunu başlatan temel serbest radikalleri dolaylı yollardan aktifleştirmesi veya lipit peroksidasyonunu doğrudan başlatması sonucu zararlı etkilerin ortaya çıkmasına neden olur (Bilici ve ark., 2001; Halliwell ve Chirico, 1993; Takım, 2015). Katalaz, hidrojen peroksiti oksijen ve suya parçalayan reaksiyonu katalizleyen bir enzimdir. $\mathrm{H}_{2} \mathrm{O}_{2}$ non radikal oksijen türüdür. Ancak hücrelerde bulunan fazla hidrojen peroksid metal iyonlarının varlığında Fenton ve HaberWeiss reaksiyonları ile hidroksit radikali oluşturarak DNA, lipit peroksidasyonu ve proteinlerdeki sistein kalıntılarının tiyol gruplarının oksidasyonuna sebep olur ve bu nedenle, $\mathrm{H}_{2} \mathrm{O}_{2}$ katalaz enzimi aracılığıyla moleküler oksijen ve suya dönüştürülmesi önemlidir (Iş̧k ve ark., 2015). Süperoksit dismutaz enzimi, süperoksit radikaline karşı devreye giren ilk savunma enzimidir ve antioksidan savunma açısından oksijene maruz kalan tüm hücrelerde önemlidir. Glutatyon proteinlerin yıkımı ve sentezinde enzimlerin düzenlenmesinde DNA' nın oluşumunda ve reaktif oksijen türleri ve serbest radikallere karşı hücrenin korunmasinda önemli bir role sahiptir (Landis ve Tower, 2005).

Bitkilerde fitokimyasal bileşiklerin tanımlanması için çeşitli teknikler kullanılır. Temel teknikler, yüksek performansl s sivı kromatografisi (HPLC), sivı kromatografi-kütle spektrometresi (LC-MS)'dir (Pandey ve ark., 2011). Bu çalışmada, A. tuncelianum'un su ekstrelerinin (ATSE); LC-MS/MS ve HPLC teknikleri ile fenolik bileşenleri karakterizasyonu yapılmış ve ratların kalp dokusunda DMBA ile oluşturulan oksidatif strese karşı antioksidan enzim düzeylerine ve lipit peroksidasyonu üzerine yapmış olduğu etkiler belirlenmeye çalışılmıştır.

\section{MATERYAL ve YÖNTEM}

\section{Bitkilerin Toplanması ve Ekstraktların Hazırlanması}

Bu çalışma için kullanılan $A$. tuncelianum, Tunceli ilinde bulunan Munzur Dağı'nın Ovacık ilçesi yönüne bakan yamaçlarından ağustos ayının ikinci haftası içerisinde 
toplandı. İnönü Üniversitesi Fen Edebiyat Fakültesi Biyoloji Bölümü Botanik Anabilim Dalı tarafindan tür tespiti doğrulandı. Ekstrakte edilene kadar $+4{ }^{\circ} \mathrm{C}$ ' de buzdolabinda muhafaza edildi. Ekstraksiyon işlemi hayvan ve in vitro antioksidan çalışması için; \% 50 (v/v) etanol-su çözücü karışımı kullanıldı. Havanda iyice ezilen sarımsak üzerine sarımsak/çözücü oranı 1/10 olacak şekilde çözücü ilave edilip ağzı kapalı olarak 24 saat çalkalayıcıda karıştırıldı. Sarı-yeşil renkte bir ekstre elde edildi. Ekstre süzme işlemine tabi tutuldu. Biyokimyasal aktivite çalışması için evaporatörde çözücü uzaklaştırıldı. $10.35 \mathrm{~g}$ yaş sarımsaktan $2.14 \mathrm{~g}$ kuru ekstre elde edildi. LC-MS/MS ve HPLC analiz çalışması için ise yukarıda anlatıldığı şekilde elde edilen ekstraktlar üzerine ekstrakt/saf su oranı 1/5 olacak şekilde saf su eklenip ekstraktın çözülmesi sağlanmıştır. Açık sarı renkte bir çözelti elde edildi. Çözücü liyofilizatörde uzaklaştırılıp kuruyan maddenin hava ile fazla temasina izin verilmeden $+4^{\circ} \mathrm{C}$ de buzdolabinda muhafaza edildi. Sarımsak örnekleri etüv firınında $103^{\circ} \mathrm{C}$ ' de 3 saat bekletmek suretiyle sabit tartıma getirildikten sonra kuru madde miktarları belirlendi. \% 61.92 oraninda nem ve \% 38.08 oraninda kuru madde içerdiği tespit edildi. Analiz sonuçları bu oranlar dikkate alınarak hesaplandl.

\section{Fenolik Bileşen Analizi}

$\mathrm{Bu}$ kapsamda Allium tuncelianum su ekstrelerinde biyoaktif bileşen analizi, LC-MS/MS ve HPLC ile analizi yapılmıştır. LC-MS/MS analizi; Dicle Üniversitesi Merkezi Araştırma Laboratuvarı ve HPLC analizi ise Harran Üniversitesi Merkezi Araştırma Laboratuvarlarından Hizmet alımı şeklinde yapılmıştır.

\section{Fenolik Bileşiklerin LC-MS / MS ile Tayini}

LC-MS/MS ile fenolik bileşiklerin analizi, ikili MS cihazı bağlanmış bir Nexera modeli Shimadzu HPLC kullanılarak yapıldı. Sıvı kromatografisi LC-30AD ikili pompa, DGU-20A3R degazör, KTO-10AS vp kolon firmı ve SIL-30AC otomatik örnekleyici ile donatılmıştır. Kromatografik ayırma, C18 ters-faz analitik kolonu Inertsil ODS-4 $(150 \mathrm{~mm} \times 4.6 \mathrm{~mm}, 3 \mu \mathrm{m})$ ile gerçekleştirildi. Kolon sıcaklığ $40^{\circ} \mathrm{C}^{\prime}$ de sabit tutuldu. Elüsyon gradienti mobil faz A (su, $5 \mathrm{mM}$ amonyum format ve \% 0.1 formik asit) ve mobil faz B (metanol, $5 \mathrm{mM}$ amonyum format ve \% 0.1 formik asit) ile oluşturuldu. Gradient programı B çözücüsünün aşağıdaki değerlerine göre $\mathrm{t}(\mathrm{dk})$ uygulanmıştır. $\mathrm{B} \%$ : (0.40), (20.90), (23.99, 90), (24.40), (29.40). Çözücü akışhızı $0.5 \mathrm{~mL} / \mathrm{dk}$ olarak uygulandı ve enjeksiyon hacmi $4 \mu \mathrm{L}$ olarak ayarland. MS tespiti Shimadzu LC-MS 8040 modeli üçlü, dört kutuplu ve hem pozitif hem negatif iyonizasyon modlarında ESI kaynak işletimi ile donatılmış kütle spektrometresi kullanılarak yapıldı. LC-MS/MS verileri Lab Solutions yazllımı (Shimadzu, Kyoto, Japonya) ile elde edilerek hesaplamalar yapıldı. Çoklu reaksiyon takip işlemi (MRM) modu analizi ölçmek için kullanıldı. Deneyde her bir bileşik analizi için üç kez uygulama yapıldı. Birinci kantitatif sonuçlar için ikinci ve üçüncü analizler ise teyit için yapıldı. Optimum ESI parametreleri; $350^{\circ} \mathrm{C}$ ara yüz sıcaklığı, $250^{\circ} \mathrm{C} \mathrm{DL}$ sicaklığı, $400^{\circ} \mathrm{C}$ isı bloğu sıcaklığı, $3 \mathrm{~L} /$ dak. Nebullizer gaz akışı ve $15 \mathrm{~L} /$ dak. kurutucu gaz akışı olarak belirlendi (Köksal ve ark., 2017).

\section{Fenolik bileşiklerin HPLC ile tayini}

$A$ tuncelianum su özütlerinin sıvı kromatografisi Karaoğul ve Kireçci (2016) yöntemi ile gerçekleştirilmiştir. Analiz, Shimadzu HPLC sistemi üzerinde, LC-20AD pompa sistemi ve bir SPD-20A UV detektörü ile gerçekleştirildi. Fenolik bileşikleri tespit etmek için kullanılan dalga boyları $278 \mathrm{~nm}$ idi. Kullanilan kolon bir ODS Hypersil C-18 (250 x 4.6 mm x 5 um) idi. Elüsyon,\% 0.1 fosforik asit (A) ve asetonitril (B) ile gerçekleştirildi. Akış hızı 0 dak,\% 8 B; 35 dakika,\% 22 B; 45 dakika\% 8 B mL/dakika idi. Kromatografik kolon, 10 dakika boyunca dengelenmesi için başlangiç koşullarıyla yıkandı. Her bileşiğin konsantrasyonları, HPLC'ye göre belirlenen bileşikler, firında kurutulmuş A. tuncelianum'un toplam ağırlı̆̆ temelinde toplam $\mathrm{mg} / \mathrm{kg}$ bazında ve yüzde olarak rapor edildi. Standart ve örnek spektrumları analiz edilen tüm numunelerde belirlenmeye çalışıldı. Tüm kalibrasyon eğrileri, dört farklı konsantrasyonda referans çözeltideki 7 marker bileşeninin konsantrasyonlarına (y, mg/kg) karşı entegre zirve alanlarının (x) doğrusal regresyon analizine dayanılarak çizilmiştir. HPLC'de 37 marker bileşeninin regresyon denklemi, ayrılma süresi ve korelasyon katsayısı Çizelge 2'de listelenmiş̧ir.

\section{Hayvan deneyleri}

$\mathrm{Bu}$ çalışma İnönü Üniversitesi Etik Kurulu'nun 10.04.2014 tarihli, 2014/A-35 Protokol No' lu etik kurulu raporunda belirtilen izinle gerçekleştirildi.

\section{Hayvanların temini ve grupların oluşturulması}

$\mathrm{Bu}$ çalışmada kullanılan Wistar albino tipi dişi ratlar İnönü Üniversitesi Araştırma Laboratuvarı, Deney Hayvanları Üretim Merkezi' (INNÜDEHÜM) den alındı. Deney boyunca, havalandırması ve güneş ışı̆̆ olan odalarda her gün altları temizlenen deney kafesleri içerisinde tutuldu. Yeterli miktarda standart pellet yem ile 30 gün boyunca beslenmiştir. Her grupta 8 adet ( $=$ 8) hayvan olmak üzere 5 grup oluşturuldu. Ratlara verilen DMBA dozlarında ve uygulama sürelerinde Banerjee ve arkadaşlarının (2003) çalışmaları esas alındr.

\section{Hayvanlarm beslenmesi ve ekstraktların uygulanması}

1. Grup: K Grubu; kontrol grubudur. Çizelge 1' de besin içeriği verilen standart diyetle beslendi.

2. Grup: D Grubu; Standart diyetle beslenip oksidatif stres oluşturması için 7,12-DMBA, $20 \mathrm{mg} / \mathrm{kg}$ vücut ağırlığı dozunda tek seferde intraperitonal olarak 0.5 $\mathrm{mL}$ enjekte edildi. 
3. Grup: DA-1 Grubu; $20 \mathrm{mg} / \mathrm{kg}$ vücut ağırlığı dozunda tek seferde intraperitonal olarak $0.5 \mathrm{~mL}$ enjekte edilen 7,12-DMBA' ya ilaveten, uygulama dozu 250 $\mathrm{mg} / \mathrm{kg}$ vücut ağırlığı dozunda olacak şekilde $A$. tuncelianum ekstraktından $1 \mathrm{~mL}$ ratlara ağızdan

4. orogastrik yöntemiyle bir ay boyunca her gün verildi.

5. Grup: DA-2 Grubu; $20 \mathrm{mg} / \mathrm{kg}$ vücut ağırlığı dozunda tek seferde intraperitonal olarak $0.5 \mathrm{~mL}$ enjekte edilen 7,12-DMBA' ya ilaveten uygulama dozu 500 $\mathrm{mg} / \mathrm{kg}$ vücut ağırlığı dozunda olacak şekilde $A$. tuncelianum ekstraktından $1 \mathrm{~mL}$ ratlara ağızdan

6. orogastrik yöntemiyle bir ay boyunca her gün verildi.

7. Grup: DE Grubu; $20 \mathrm{mg} / \mathrm{kg}$ vücut ağırlığı dozunda tek seferde intraperitonal olarak

8. $0.5 \mathrm{~mL}$ enjekte edilen 7,12-DMBA' ya ilaveten standart bir antioksidan olan E vitamini, uygulama dozu $200 \mathrm{mg} / \mathrm{kg}$ vücut ağırlığı dozunda olacak şekilde bir ay boyunca haftada iki kez ağızdan orogastrik yöntemiyle verildi.

Yemler, özel çelik kaplarda ve su ise paslanmaz çelik bilyeli biberonlarda normal çeşme suyu olarak verildi.

Hayvanların Dekapite Edilmesi ve Gerekli Dokularm Alinmasi

Hayvanlar 30 gün bu şekilde İnönü Üniversitesi Araştırma Laboratuvarı, Deney Hayvanları Üretim Merkezi' (INNÜDEHÜM) çalışanları tarafindan beslendi. $100 \mathrm{mg} / \mathrm{kg}$ Ketamin Hidroklorür (Ketamidor-Richte Pharma) ve $5 \mathrm{mg} / \mathrm{kg}$ ksilazine (Rompun-Bayer) olacak şekilde intraperitonal yoldan verilerek öldürüldü. Kanları ana arterden alınıp, vakumlu tüplere aktarıldı. Aynı gün kan lipit düzeylerine bakılmak üzere $+4{ }^{\circ} \mathrm{C}$ 'de saklandı. Hayvanların dokuları, cerrahi tekniklerle alındı ve izotonik sodyum klorür $(0.9 \% \mathrm{NaCl})$ ile perfüze edilip temizlenerek iki kısma ayrıldı. Birinci kısım enzim aktivite tayini için, ikinci kısım ise lipit peroksidasyonunu belirlemek için homojenize edildi.

Çizelge 1. Deney Hayvanları Besin İçeriği

\begin{tabular}{ll}
\hline Yem maddeleri & $\begin{array}{l}\text { Yüzdesi } \\
(\%)\end{array}$ \\
\hline Buğday & 10 \\
Misir & 21 \\
Arpa & 14 \\
Kepek & 8 \\
Soya Küspesi & 25 \\
Balık Unu & 8 \\
E-Kemik unu & 4 \\
Melas & 4 \\
Tuz & 4 \\
*Vitamin Karması & 1 \\
**Mineral Karması & 1 \\
\hline
\end{tabular}

*Vitamin karmas1: Deney hayvanlarına verilen yemlerin vitamin karmasinda A, D3, E, K, B1, B2, B6, B12 vitaminleri ile nikotinamit, folik asit, D-biotin ve kolin bulunmaktadır. **Mineral karması: Mangan, demir, çinko, bakır, iyot, kobalt, selenyum ve kalsiyumdan oluşmuştur.

\section{Dokularin Homojenizasyonu}

Enzim aktivitesi yapılacak dokuların homojenizasyonunda, $1 / 20 \quad(\mathrm{w} / \mathrm{v})$ oranında PBS tamponu $(\mathrm{pH} 7,4)$ eklenerek buz izolasyonu altında homojenizatör (IKA-Werke T25 marka) ile homojenize edildi. Elde edilen homojenatlar, sonifikatörde (VWR Branson scientific) 30 saniyelik aralıklarla 4 defa 30 saniye sonifiye edildi. $10,000 \mathrm{~g}$ de $+4{ }^{\circ} \mathrm{C}^{\prime}$ de 10 dakika mikrosantrifüj aletiyle (Nüve NF 800R) santrifüj işlemi yapıldı ve böylece enzim aktiviteleri ve protein tayininin yapılacağ Süpernatan örnekleri ölçüm işlemleri yapılıncaya kadar $-70{ }^{\circ} \mathrm{C}$ 'de derin dondurucuda saklandı. Lipit peroksidasyonunu belirleyeceğimiz dokunun homojenizasyonu ise PBS tamponu ( $\mathrm{pH}$ 7.4) ile 1/10 $(\mathrm{w} / \mathrm{v})$ oranında eklenerek hazırlandı ve hemen deneyler yapıldı.

\section{Antioksidan enzim aktivitesi analizleri}

\section{Katalaz enzim aktivitesi analizi}

Katalaz enziminin aktivite tayini, Eşrefoğlu ve arkadaşlarının (2006) yöntemi modifiye edilerek, $A$. tuncelianum su özütleri için uygulandı. Reaksiyon ortamı için gerekli olan çözeltiler: $0.066 \mathrm{M} \mathrm{Na}$, K-fosfat tamponu $\left(\mathrm{Na}_{2} \mathrm{HPO}_{4}-\mathrm{KH}_{2} \mathrm{PO}_{4} ; \mathrm{pH}: 7\right)$ ve derişik $\mathrm{H}_{2} \mathrm{O}_{2}(\%$ 35'lik) çözeltisi hazırlandı. Katalaz ölçümünde kullanılmak üzere spektrofotometrede (Shimadzu 1601-UV visible); 240 nm'de absorbans 0.7-0.9 aralığına sabitleninceye kadar $\mathrm{Na}-\mathrm{K}$-fosfat tampon çözeltisine derişik $\mathrm{H}_{2} \mathrm{O}_{2}$ ilave edildi. Numunelerin katalaz içeriğini belirlemek için hazırlanan bu karışımdan $1000 \mu \mathrm{L}$ alınıp küvete kondu ve üzerine çalışma aralığına bağlı olarak $30 \mu \mathrm{L}$ başlayarak gittikçe artan konsantrasyonlarda süpernatant eklendi. Bir kez karıştırılıp spektrofotometrede 240 $\mathrm{nm}$ dalga boyunda 30 sn süreyle $\mathrm{H}_{2} \mathrm{O}_{2}$ 'nin $(\varepsilon=0.0396$ $\left.\mathrm{cm}^{2} \mu \mathrm{mol}^{-1}\right)$ absorbans değişimi okundu. Okunan bu optik dansite farkından mL'deki enzim ünite sayısı aşağıdaki eşitlikten hesaplandı.

$\mathrm{C}=\Delta \mathrm{OD} / 6220 / \mathrm{mL}$ örnek $\Delta \mathrm{OD}$ : Optik Dansite Farkı

\section{Süperoksit dismutaz enzim aktivitesi analizi}

SOD enziminin aktivite tayini Vardi ve arkadaşlarının (2008) yöntemi modifiye edilerek, A. tuncelianum su özütleri için uygulandı. Yöntemin esası ksantin/ksantin oksidaz sisteminde üretilen süperoksit radikallerinin sitokrom-c'yi indirgemesinin SOD tarafindan inhibisyonu temeline dayanmaktadır. Süperoksit dismutaz çeşitli yollarla ortaya çıkan süperoksit $\left(\mathrm{O}_{2}\right)$ radikalinin hidrojen peroksite $\left(\mathrm{H}_{2} \mathrm{O}_{2}\right)$ dismutasyonu reaksiyonunu katalizler. SOD enzim aktivitesi ksantin/ksantin oksidaz (XO) sistemi ile üretilen $\mathrm{O}_{2}$ radikallerinin sitokrom c'yi okside etmesi sonucu oluşan renk değişiminin inhibisyonu $550 \mathrm{~nm}$ 'de takip edilerek belirlendi. Bu reaksiyona dayanan optik dansitedeki azalmadan yararlanarak SOD tarafindan reaksiyonun \% inhibisyonu belirlendi. Bu reaksiyonu \% 50 inhibe eden örneklerdeki SOD miktarı 1 Ünite 
(U) olarak kabul edildi ve sonuçlar $\mathrm{U} / \mathrm{mg}$ protein olarak verildi.

$\%$ inhibisyon $=\left(\left(\mathrm{OD}_{\text {kör }}-\mathrm{OD}_{\text {örnek }}\right) / \mathrm{OD}_{\text {kör }}\right) \times 100 \quad \mathrm{OD}{ }_{\text {optik Dansite }}$

\section{Total glutatyon (GSH) ölçümü}

Supernatant içindeki GSH miktarı, ticari bir GSH standart olarak kullanılarak, $\mathrm{nmol} / \mathrm{mg}$ protein cinsinden belirlendi (Akerboom and Sies, 1981). Reaksiyon ortamı için gerekli olan çözeltiler: Fosfat tampon (pH:7), Tampon çözelti (DTNB $1.5 \mathrm{mg} / \mathrm{mL}$ ), $\mathrm{NADPH} \quad 4 \mathrm{mg} / \mathrm{mL}$ (tamponda hazırlanır), GSHRedüktaz (6 Unıt/mL) hazırlandl. Spektrofotometre küvetine $1 \mathrm{~mL}$ tampon çözeltisi konulup, üzerine $30 \mu \mathrm{L}$ örnek, $50 \mu \mathrm{L} \mathrm{NADPH,} 20 \mu \mathrm{L}$ DTNB, $20 \mu \mathrm{L}$ GSHRedüktaz ilave edildi. Daha sonra spektrofotometrede (Shimadzu 1601-UV visible) 412 nm'de absorbans değişimi (5. dk) okundu. Enzim aktivitesi U/mg protein olarak ifade edildi.

\section{Protein tayini}

Protein tayini; Bradford (1976) yöntemi esas alınıp, Ateş ve arkadaşlarının (2008) yöntemi modifiye edilerek, A. tuncelianum su özütleri için uygulandı. Standart protein olarak bovin serum albumin (BSA) kullanıldı. BSA'dan $1 \mathrm{mg}$ tartıp $1 \mathrm{~mL}$ de çözülmüş ve bu çözelti de 1000, 500, 400, 300, 200, 100, 75, 50, 25 ve $10 \mathrm{mg} / \mathrm{mL}$ olacak şekilde çeşitli derişimlerde çözeltileri hazırlandı. 20 Kat seyreltilmiş örnek ve standarttan $25 \mu \mathrm{L}$ (üçer tekrarl olacak şekilde) mikroplate yerleştirildi. Üzerine $200 \mu \mathrm{L}$ Bradford çözeltisi eklendi. 595 nm'de okuma yapıldı. Standartlardan elde edilen verilerle standart grafiği çizilmiş ve bu grafikten elde edilen formülden örnekteki protein değeri hesaplandı.

\section{Lipit peroksidasyon ölçümü}

Serbest radikal saldırıları sonucu hücre membranında bulunan, lipitlerin peroksidasyon son ürünü olan malondialdehit (MDA) miktarı Dinis ve arkadaşlarının (1994) yöntemine göre modifiye edilerek belirlendi. $10 \mathrm{~mL}$ 'lik santrifüj tüpleri alındı ve bütün tüplere $1.5 \mathrm{~mL}$ TCA çözeltisi konuldu. Kör tüpleri hariç tutularak örnek tüplerine $0.5 \mathrm{~mL}$ homojenat konuldu. Kaynar suda $\left(95-100^{\circ} \mathrm{C}\right.$ de) $60 \mathrm{dk}$. bekletildi. Üzerindeki süpernatan alınıp üzerine $1 \mathrm{~mL}$ TBA eklendi. Kaynar suda ( 95-100 ${ }^{\circ} \mathrm{C}$ 'de ) $60 \mathrm{dk}$. bekletildi. Daha sonra tüpler soğutuldu ve 3500 rpm' de $10 \mathrm{dk}$ santrifüj edildi. Üzerindeki süpernatan alınıp üzerine $1 \mathrm{~mL} \mathrm{n}$-Bütanol eklenip vortekslendi. $30 \mathrm{dk}$. sonra üzerindeki organik faz alınıp Shimadzu 1601 UV-VIS spektrofotometresinde 550 nm'deki MDA-TBA kompleksinin ( $\varepsilon: 1.56 \times 10^{5} \mathrm{M}^{-1} \mathrm{~cm}{ }^{1}$ ) absorbans1 okunarak malondialdehit miktarı hesaplandı.

\section{İstatiksel Değerlendirme}

Çalışma bulgularının istatiksel analizinde GraphPhad Prism 5.01 programı kullanıldı. Verilerin kıyaslaması
One Way ANOVA Tukey testi kullanılarak gerçekleştirildi. Sonuçlar; grup ortalamaları \pm standart sapma şeklinde verildi. Sonuçlar değerlendirilip, gruplar birbirleri ile karşılaştırılırken istatistiksel anlamlllık $(P<0,05)$ olarak kabul edildi. $\mathrm{P}<0,05$; "Gruplar arasında istatistiksel olarak anlamlı fark var" olarak ifade edildi. Eğer bir grup kontrol grubu ile karşılaştırılıyor ve anlamlı bir farklılık söz konusu ise; (*) ile gösterildi. Ĕger gruplar kendi aralarında karşılaştırıllyor ise istatistiksel anlamlılık $(P<0,05) ; \mathrm{a}, \mathrm{b}, \mathrm{c}, \mathrm{vb}$. harfleri ile gösterildi.

\section{BULGULAR ve TARTISSMA}

A.tuncelianum ekstraktının LC-MS/MS ile ölçülen fenolik bileşiklerin bileşimi

Bitki materyalinde yaygin olan 37 fenolik bileşik, LCMS/MS yöntemi ile analiz edildi. Bitki kimyasal bileşiklerini belirlemek için kullanılan 37'lik analiz yöntemi Yılmaz (2015) tarafından geliştirildi ve $A$. tuncelianum su ekstraktları (ATSE) için kullanıldı. Standart bileşiklerin ve ATSE' nin LC-MS/MS kromatogramları sırasıyla Şekil 1 ve Şekil 2'de verilmiştir. ATSE' nın, analiz edilen ve tanımlanan bileşiklerin konsantrasyonları Çizelge 2'de verilmiştir. Çalışma sonucunda, miktar olarak en yüksek bileşiğin Pirokatekol; 7477.12 \pm 1.75 pg Analit/g ATSE olduğu bulundu. Pirokatekol konsantrasyonu çok yüksekti diğer piklerin görünürlüğünü etkilmesine neden oldu. Çalışmamızın ikinci en yüksek miktarlı bileşiği, kainik asit (4821.13 $\pm 0.39 \mathrm{\mu g}$ Analit/g ATSE) olarak belirlendi. Sonra, sırasiyla; Sinamik asit, Hesperidin, Kumarin, Vanilik asidi, Fumarik asit, Ferulik asit, Gallik asit ve P- Kumarik asit olmak üzere toplam 10 bileşik tespit edildi. ATSE ' nın fenolik çeşitliliği yönünden fakir olduğu görüldü.

Yaptığımız literatür taramasında A. sativum içeriği için yapılan LC-MS/MS çalışmasında; sitrik asit izositrik asit, fitalik asit, kafeik asit, ferulik asit, kuersetin, kafeik asit, kaempferol ve isorhamnetin bileşikleri belirlenmiştir (Farag ve ark., 2017). Literatürde diğer endemik sarımsak türlerine ait LCMS/MS analiz sonuçları, pg Analit/g sarımsak olmak üzere şu şekilde bulunmuştur; Allium akaka türünün en yüksek analit değerleri, hesperidin (3700.94 $\mathrm{\mu g}$ Analit/g ekstre) ve rutin (3015.87 $\mu \mathrm{g}$ Analit/g ekstre) olarak belilenmiştir. Allium atroviolaceum türünün malik asidin (1980.31 pg Analit/g ekstre) en yüksek değerde bulunduğu tespit edilmiştir. Allium chrysantherum türünün en yüksek analit değerinin yine malik asit (889.21 $\mathrm{\mu g}$ Analit/g ekstre) olduğu görülmüştür. Allium kharputense türünün toprak altı ve toprak üstü kısımlarının sonuçlarına göre çok yüksek değerde analit bulunamamıştır. Toprak altı kısminda vanilin (172.58 $\mathrm{\mu g}$ Analit/g ekstre) miktarının en yüksek olduğu görülmüştür (Aras, 2016). Ayrica Allium scorodoprasum subsp. roturdum türünün en yüksek analit değerinin malik asit (787.6 
ug Analit/g ekstre) olduğu belirlenmiştir. Allium vineale türünün en yüksek analit miktarının malik asit (3304.12 $\mu \mathrm{g}$ Analit/g ekstre) olduğu belirlenmiştir (İzol, 2016). Genel olarak Allium türlerinin en yüksek miktarda bulunan analitin çoğunlukla bitkilerde rastlanan malik asit olduğu görülmektedir. Genel olarak, incelenen tüm sarımsak türlerinin fenolik içeriğinin, LC-MS/MS sonuçlarına göre çeşitlilik ve miktar açısından zayıf olduğu saptanmıştır. Bu verilerin bizim sonuçlarla paralel olduğu görülmüştür.

$(\mathrm{x} 100.000)$

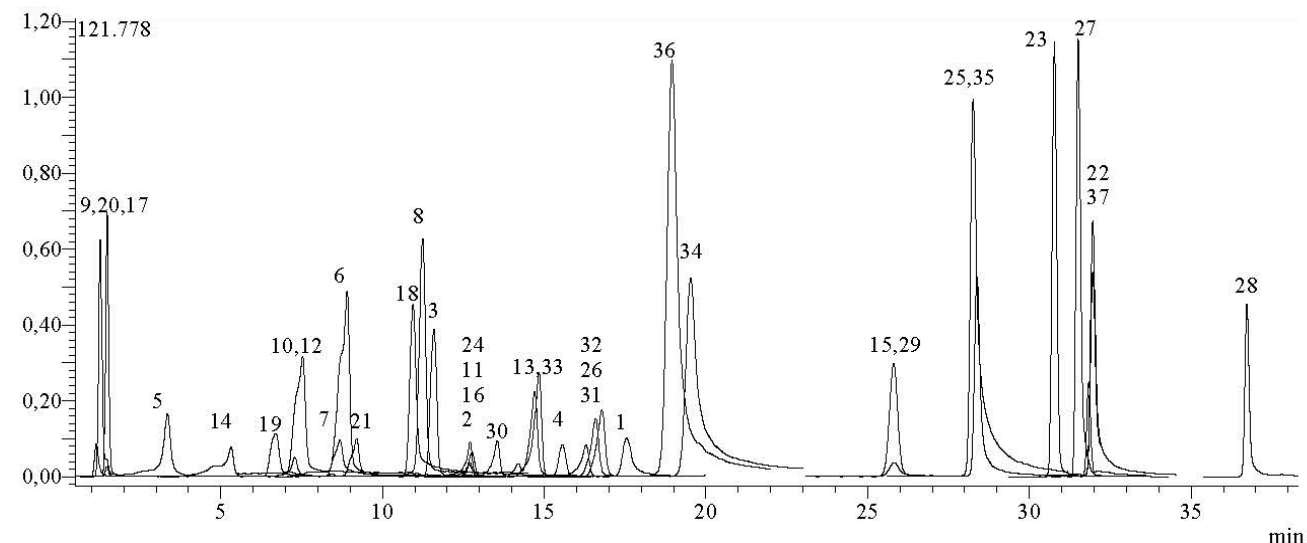

Şekil 1. Standart karışımın LC-MS/MS kromatogramı.

Standart bileşikler: 1: Kumarin, 2: Hesperidin, 3: P-Kumarik asit, 4: O-Kumarik asit, 5: Gallik asit, 6: Kafeik asit, 7: Vanilik asit, 8: Salisilik asit, 9: Kainik asit, 10: 4-OH-benzoik asit, 11: Ferulik asit, 12: Klorojenik asit, 13: Rozmarinik asit, 14: Protokateşik asit, 15: Sinamik asit, 16: Sinapinik asit, 17: Fumarik asit, 18: Vanilin, 19: Pirokatekol, 20: Malik asit, 21: Syringik asit, 22: Hesperetin, 23: Naringenin, 24: Rutin, 25: Kuercetin, 26: Kuercitrin, 27: Apigenin, 28: Krisin, 29: Liquiritigenin, 30: İzokersitrin, 31: Apigetrin, 32: Rhoifolin, 33: Nikotiflorin, 34: Fisetin, 35: Luteolin, 36: Myrisetin, 37: Kaempferol

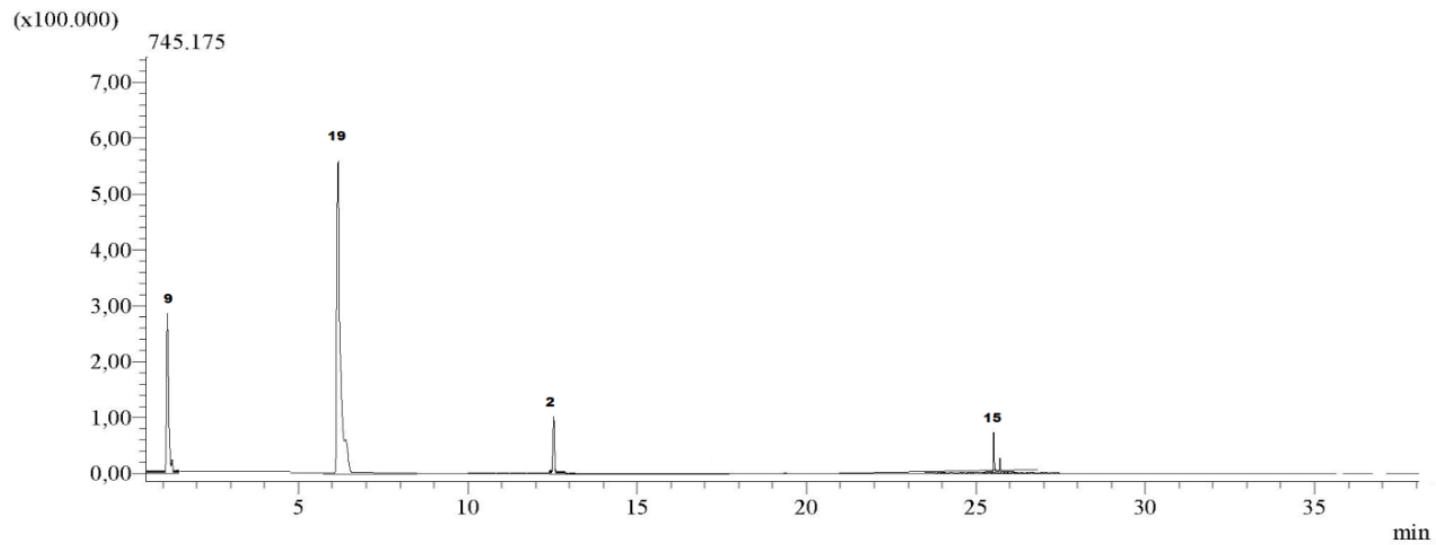

Şekil 2. ATSE içindeki fenolik bileşiklerin LC-MS/MS kromatogramı.

Grafikte; kainik asit (9 no'lu pik), Pirokatekol (19 no'lu pik), Hesperidin (2 no'lu pik) ve Sinamik asit (15 no'lu pik) belirgin olarak görülmektedir. Belirlenen diğer 6 bileşik ise çok düşük miktarda bulundukları için grafiğe yansımamıştır. 
Çizelge 2. ATSE içindeki fenolik bileşiklerin $\mu \mathrm{g}$ analit/g ATSE olarak bileşimi ve LC-MS/MS yönteminin analitik parametreleri

\begin{tabular}{|c|c|c|c|c|c|c|c|c|c|c|c|}
\hline $\begin{array}{l}\text { No } \\
\text { (pik) }\end{array}$ & Analit & $\mathrm{RT}^{\mathrm{c}}$ & $\begin{array}{l}\text { Parent } \\
\text { Iyon } \\
(\mathrm{m} / \mathrm{z}) \mathrm{a}\end{array}$ & Regresyon Denklemi & $\mathrm{R}^{2 \mathrm{~d}}$ & RSD \% e & $\begin{array}{l}\text { Doğrusallık } \\
\text { alan (mg/L) }\end{array}$ & $\begin{array}{l}\mathrm{LOD} / \mathrm{LOQ} \\
(\mathrm{\mu g} / \mathrm{L})^{\mathrm{f}}\end{array}$ & $\begin{array}{l}\text { MRM }^{\mathrm{b}} \\
(\%)\end{array}$ & $\mathrm{Ug}^{\mathrm{g}}$ & $\begin{array}{l}\text { Niceleme ( } \mathrm{pg} \\
\text { Analit / g ATSE) } \\
\mathrm{h}\end{array}$ \\
\hline 1 & Kumarin & 17.40 & 147.05 & $y=33.64 \times-89700$ & 0.994 & 0.01306 & $1000-20000$ & $208.4 / 228.4$ & 0.99947 & 0.0237 & $6.67 \pm 0.0015$ \\
\hline 2 & Hesperidin & 12.67 & 610.90 & $y=1340.27 \times-43769$ & 0.998 & 0.00945 & $25-1000$ & $3.4 / 4.2$ & 1.01733 & 0.0262 & $12.31 \pm 0.003$ \\
\hline 3 & P- Kumarik asit & 11.53 & 162.95 & $y=3199.20 x+13002$ & 0.992 & 0.01820 & $25-1000$ & $7.3 / 9.1$ & 1.00617 & 0.0516 & $0.22 \pm 0.001$ \\
\hline 4 & O- Kumarik asit & 15.45 & 162.95 & $y=1219.34 \times-10915$ & 0.999 & 0.02730 & $25-1000$ & $24.4 / 31.1$ & 0.98344 & 0.0513 & N.D \\
\hline 5 & Gallik asit & 3.00 & 168.85 & $y=226.76 x+38152$ & 0.998 & 0.01601 & $250-10000$ & $95.5 / 106.9$ & 1.00004 & 0.0282 & $0.89 \pm 0.0001$ \\
\hline 6 & Kafeik asit & 8.80 & 178.95 & $y=3963.32 x+178156$ & 0.998 & 0.01454 & $25-1000$ & $18.4 / 22.4$ & 1.00917 & 0.0354 & N.D \\
\hline 7 & Vanilik asit & 8.57 & 166.90 & $y=35.84 \times-12097$ & 0.999 & 0.00528 & $1000-20000$ & $122.2 / 139.7$ & 1.00093 & 0.0508 & $5.6 \pm 0.002$ \\
\hline 8 & Salisilik asit & 11.16 & 136.95 & $y=5286.26 x+309192$ & 0.989 & 0.01016 & $25-1000$ & $5.0 / 6.5$ & 1.00989 & 0.0329 & N.D \\
\hline 10 & 4-OH-benzoik asit & 7.39 & 136.95 & $y=409.03 x+112079$ & 0.998 & 0.01284 & $250-10000$ & $33.2 / 38.1$ & 0.99662 & 0.0289 & N.D \\
\hline 11 & Ferulik asit & 12.62 & 192.95 & $y=80.45 \times-31782$ & 0.997 & 0.00708 & $250-10000$ & $36.6 / 42.0$ & 0.99987 & 0.0494 & $1.06 \pm 0.0005$ \\
\hline 12 & Klorojenik asit & 7.13 & 353.15 & $y=781.36 \times-18697$ & 0.998 & 0.00058 & $25-1000$ & $6.2 / 8.1$ & 1.00806 & 0.0069 & N.D \\
\hline 13 & Rozmarinik asit & 14.54 & 359.00 & $y=909.67 \times-201692$ & 0.994 & 0.02014 & $100-5000$ & $6.6 / 8.8$ & 0.99206 & 0.0713 & N.D \\
\hline 14 & Protokateşik asit & 4.93 & 152.95 & $y=297.75 x+30590$ & 0.995 & 0.01236 & $100-5000$ & $28.2 / 31.4$ & 0.99404 & 0.0411 & N.D \\
\hline 15 & Sinnamik asit & 25.61 & 147.00 & $y=9.06 x-12403$ & 0.996 & 0.00648 & $5000-20000$ & $821.8 / 859.7$ & 1.00051 & 0.0143 & $64.94 \pm 0.009$ \\
\hline 16 & Sinafinik asit & 12.66 & 222.95 & $y=141.96 \times-73294$ & 0.992 & 0.01446 & $250-10000$ & $78.7 / 86.1$ & 1.00164 & 0.0281 & N.D \\
\hline 17 & Fumarik asit & 1.48 & 115.00 & $y=64.99 \times-11592$ & 0.997 & 0.00536 & $100-5000$ & $28.1 / 34.5$ & 0.99748 & 0.0124 & $1.56 \pm 0.0001$ \\
\hline 18 & Vanillin & 10.87 & 151.00 & $y=446.10 x+70934$ & 0.998 & 0.00696 & $250-10000$ & $44.3 / 53.1$ & 0.99679 & 0.0280 & N.D \\
\hline 19 & Pirokatekol & 6.48 & 109.00 & $y=30.61 x+14735$ & 0.996 & 0.01313 & $1000-20000$ & $261.1 / 278.4$ & 0.99987 & 0.0235 & $7477.12 \pm 1.75$ \\
\hline 20 & Malik asit & 1.23 & 133.00 & $y=316.95 \times-42041$ & 0.999 & 0.00477 & $250-10000$ & $55.3 / 67.5$ & 1.01266 & 0.0113 & N.D \\
\hline 22 & Hesperetin & 31.76 & 300.95 & $y=876.67 x+48916$ & 0.997 & 0.03209 & $25-1000$ & $5.6 / 6.9$ & 0.98850 & 0.0562 & N.D \\
\hline 23 & Naringenin & 30.68 & 270.95 & $y=4315.1 x+178410$ & 0.995 & 0.02054 & $25-1000$ & $5.4 / 6.4$ & 0.99883 & 0.0521 & N.D \\
\hline 24 & Rutin & 12.61 & 609.05 & $y=561.91 \times-16879$ & 0.997 & 0.00473 & $25-1000$ & $5.5 / 6.5$ & 1.00994 & 0.0159 & N.D \\
\hline 25 & Kuersetin & 28.17 & 300.90 & $y=1198.48 x+480562$ & 0.990 & 0.01589 & $100-5000$ & $23.3 / 28.9$ & 0.98470 & 0.0543 & N.D \\
\hline 26 & Kuersitrin & 16.41 & 447.15 & $y=339.39 x+38910$ & 0.999 & 0.01528 & $100-5000$ & $22.0 / 25.2$ & 0.99726 & 2.0079 & N.D \\
\hline 27 & Apigenin & 31.43 & 268.95 & $y=4548.36 x+295252$ & 0.990 & 0.02304 & $25-1000$ & $5.4 / 6.3$ & 1.01444 & 0.0650 & N.D \\
\hline 28 & Krisin & 36.65 & 252.95 & $y=2032.13 x+95593$ & 0.993 & 0.00490 & $25-1000$ & $5.4 / 6.2$ & 1.00338 & 2.0083 & N.D \\
\hline 29 & Likuiritigenin & 25.62 & 254.95 & $y=2384.96 x+59141$ & 0.996 & 0.01849 & $25-1000$ & $5.5 / 6.6$ & 1.00333 & 0.0341 & N.D \\
\hline 30 & İzokuersitrin & 13.42 & 463.00 & $y=803.23 x+4981$ & 0.999 & 0.00682 & $25-1000$ & $5.4 / 6.3$ & 1.00594 & 0.0133 & N.D \\
\hline 31 & Apigetrin & 16.59 & 431.00 & $y=1775.55 x+91121$ & 0.993 & 0.01797 & $25-1000$ & $5.4 / 6.1$ & 1.01394 & 0.0597 & N.D \\
\hline 32 & Roifolin & 16.11 & 577.05 & $y=237.15 x+11887$ & 0.999 & 0.00747 & $100-5000$ & $23.1 / 27.9$ & 1.01046 & 0.0941 & N.D \\
\hline 33 & Nikotiflorin & 14.68 & 593.05 & $y=498.38 x+79274$ & 0.991 & 0.00737 & $100-5000$ & $22.4 / 25.5$ & 1.02558 & 0.0276 & N.D \\
\hline 34 & Fisetin & 19.30 & 284.95 & $y=547.46 x+274791$ & 0.991 & 0.00557 & $250-10000$ & $54.4 / 61.4$ & 0.99877 & 0.0148 & N.D \\
\hline 35 & Luteolin & 28.27 & 284.75 & $y=3272.65 x+150557$ & 0.997 & 0.00575 & $25-1000$ & $5.4 / 6.5$ & 1.00772 & 0.0174 & N.D \\
\hline 36 & Mirisetin & 18.72 & 317.00 & $y=583.55 x+205727$ & 0.999 & 0.00652 & $250-10000$ & $53.2 / 57.2$ & 0.99982 & 0.0126 & N.D \\
\hline 37 & Kamferol & 31.88 & 284.75 & $y=26.29 x+87558$ & 0.992 & 0.01436 & $1000-20000$ & $206.6 / 214.3$ & 0.99971 & 0.0209 & N.D \\
\hline
\end{tabular}

[a: Yakın iyon $(\mathrm{m} / \mathrm{z})$ : Standart bilesiklerin moleküler iyonları; b: MS2 (CE): MRM iliskili moleküler iyonlar için fragmanlar; c: RT; Alıkonma süresi; d: R2; determinasyon katsayısı; e: RSD; Bağıl standart sapma; f; LOD/LOQ ( $\mathrm{gg} / \mathrm{L})$; Tespit limiti / Sınır aşma limiti; g: U (\%); 95\% Güven seviyesinde göreceli standart belirsizlik, h: Bitki ekstraktının $\mu \mathrm{g} / \mathrm{g}$ (w / w) cinsinden değerleri; N.D.: not detected (Belirlenemedi).] 


\section{A.Tuncelianum Ekstraktının HPLC ile Ölçülen} Fenolik Bileşiklerin Bileşimi

Çalışmamızda yüksek performanslı sıvı kromatografisi (HPLC) yöntemi kullanılarak, $A$. tuncelianum su ekstraktı (ATSE) içeriğinde 7 fenolik bileşik araştırıldı ve sonuç olarak 2 fenolik bileşiğe rastlandı. Bu şekilde ATSE içeriğinde bulunan toplam bileşiklerinin yaklaşık \%36.39'u belirlenmiştir. Standart bileşiklerin ve $A$. tuncelianum özütlerinin HPLC kromatogramları Şekil 3 ve şekil 4 'te verilmiştir. Analiz edilerek tanımlanan bileşiklerin konsantrasyonları Çizelge 3' te verilmiştir. Çalışmanın sonucuna göre, ekstraktın ana bileşenleri fumarik asit (\% 30.09) ve gallik asit (\% 6.30) olarak bulunmuştur.

Literatüre bakıldığında sarımsak türlewri için yapılan HPLC ile fenolik içerik çalışmaları şu şekilde bulunmuştur; Vlase ve arkadaşları (2013) Romanya'da yetiştirilen bazı allium türlerinin etanol ekstraktları ve hidrolize edilmiş özütleri üzerinde HPLC ile fenolik maddeleri araştırmış ve tüm etanolik ekstraktlarda pCoumaric asit ve ferulik asit tespit etmişlerdir. A. cepa ve $A$. sativum (Yünlü, 2011) üzerinde yapılan HPLC çalışmasında belirlenen fenolik bileşikler, galik asit, protokateşik asit, p-hidroksibenzoik asit, klorojenik asit, kafeik asit, ferulik asit, elagik asit gibi fenolik asitler ve mirisetin, kersetin, luteolin, kaempferol, isoharmnetin gibi flavonoidler olmuştur. Fratianni ve arkadaşları (2016) bazı endemik İtalyan sarımsak türlerinin polifenolik içeriğini araştırmıştır. $A$. sativum çeşitlerinin ("Bianco", "Torella", "Salomone", "Ufita Flumeri" ve "Schiacciato") yüksek düzeyde gallik asit ve klorojenik asit içerdiğini bulmuşlardır. Ayrıca eser miktarda; kafeik asit, epikateşin, hiperozid, ferulik asit, apigenin ve p-kumarik asit tespit edilmiştir. Bu sonuçlar sarımsak türlerinde fenolik bir bileşen olarak; gallik asit, fumarik asit, 4hidroksibenzoik asit, p-kumarik asit, klorojenik asit, kafeik asit ve kersetin bileşenlerinin var olduğunu ortaya koymaktadır. Bizim çalışmamız, bu sonuçlara paralel olarak çıkmakla beraber, elde ettiğimiz sonuçlar; $A$. tuncelianum'un yüksek pirokatekol seviyesine sahip olduğunu ortaya koymaktadır.

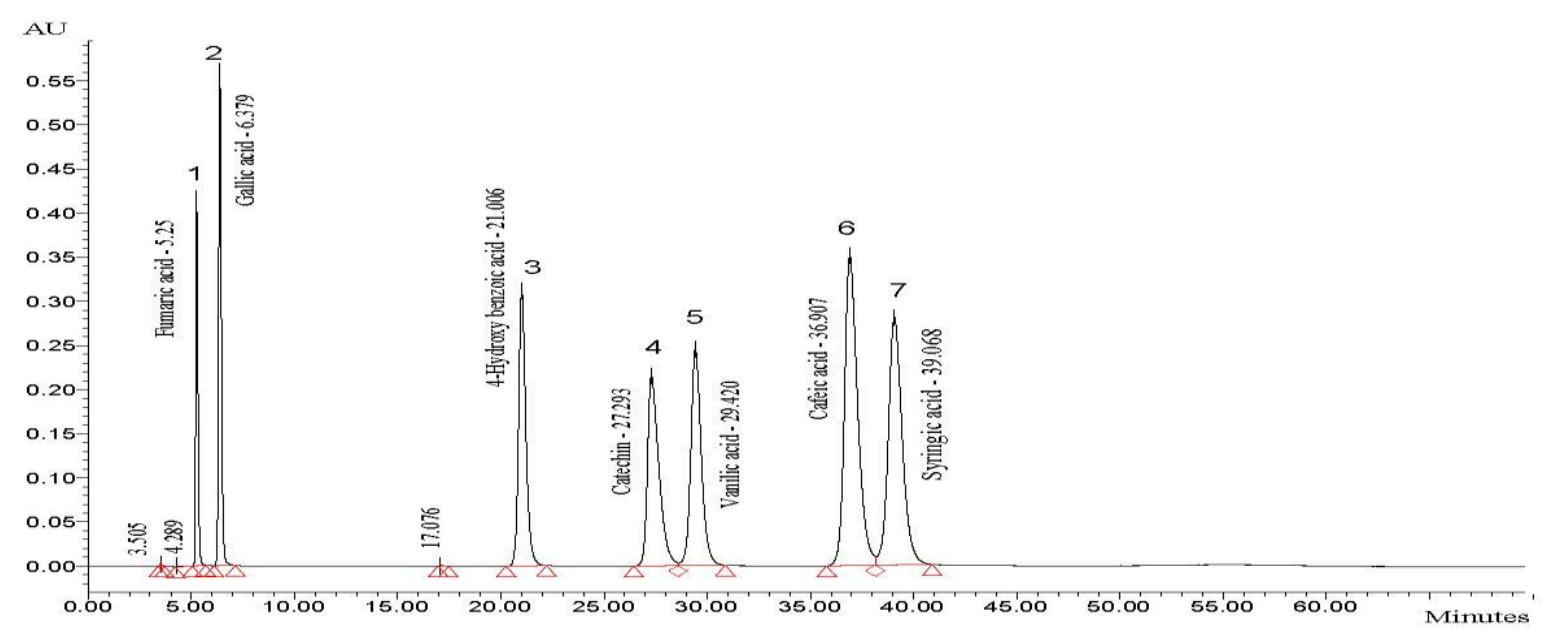

Şekil 3. Standart karışımın tipik kromatogramları. Standart bileşikler: (1) fumarik asit, (2) gallik asit, (3) 4hidroksibenzoik asit, (4) kateşin, (5) Vanillik asit, (6) Kafeik asit, (7) şirinik asit.

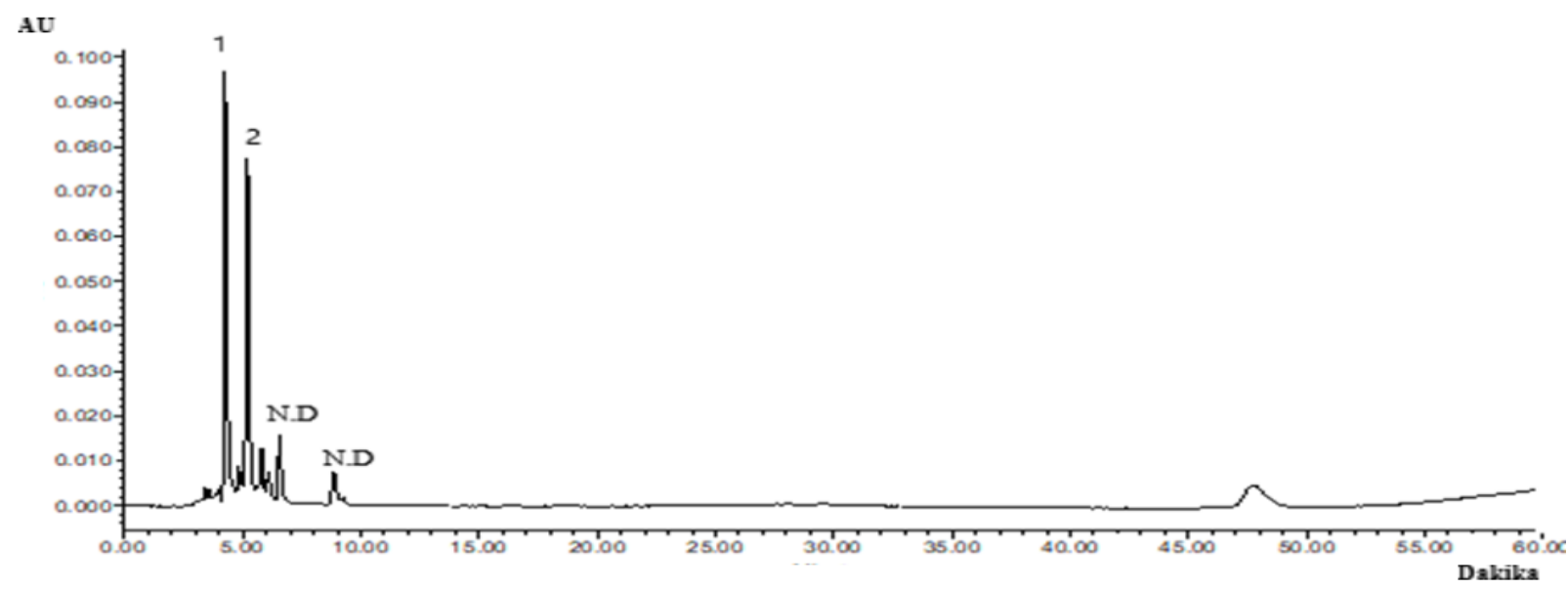

Şekil 4. ATSE fenolik bileşiklerinin HPLC kromatogramı. Grafikte, fumarik asit (1 no'lu) ve gallik asit'e (2 no'lu) ait pikler belirgin olarak görülmektedir. Tespit edilemeyen pikler N.D (No Detected) ile gösterilmiştir. 
Çizelge 3. A. tuncelianum su ekstraktında HPLC ile belirlenen bileşimi ve HPLC'nin analitik parametreleri

\begin{tabular}{llllllll}
$\begin{array}{l}\text { No } \\
\text { (Pick) }\end{array}$ & Analit & $\begin{array}{l}\text { R.T } \\
(\mathbf{m i n})\end{array}$ & $\begin{array}{l}\text { LOD/LOQ } \\
(\mathbf{m g} / \mathbf{k g})\end{array}$ & $\begin{array}{l}\text { Regresyon } \\
\text { denklemi }\end{array}$ & $\mathbf{R}^{2}$ & $\begin{array}{c}\text { Miktar (ATSE) } \\
(\mathbf{m g} / \mathbf{k g})\end{array}$ & \% \\
\hline 1 & Fumarik asit & 5.25 & $0-5000$ & y=0.0015x & 0.9985 & 1176.7 & 30.09 \\
2 & Gallik asit & 6.38 & $0-300$ & Y=5E-05X & 0.9988 & 8.35 & 6.30 \\
3 & 4-Hidroksi benzoik asit & 21.01 & $0-700$ & Y=5E-05X & 0.9988 & N.D & \\
4 & Kateşin & 27.29 & $0-2500$ & Y=0,0002X & 0.9972 & N.D & \\
5 & Vanilik asit & 29.42 & $0-800$ & Y=8E-05X & 0.9973 & N.D & \\
6 & Kafeik asit & 36.91 & $0-700$ & Y=5E-05X & 0.9986 & N.D & 36.39 \\
7 & Şirinik asit & 39.07 & $0-700$ & Y=4E-05X & 0.999 & N.D & \\
\hline
\end{tabular}

\section{Hayvan Deneyleri Sonuçları}

A.tuncelianum Ekstraktının Kalp Katalaz Enzim aktivitesine Etkisi

Katalaz enzim aktivitesi farklı dokularda değişkenlik gösterir. Katalaz enzimi, karaciğer, böbrek ve kırmızı kan hücrelerinde daha yüksek miktarda bulunur. DMBA ile indüklenmiş rat dokularında katalaz enzim aktivitesinin düşmesi anlamlı azalma olarak kabul edilmiştir. DMBA ile indüklenmiş ratlara verilen antioksidatif maddelerin ise, azalan katalaz enzim aktivitesini yükseltmeleri anlamlı artma olarak rapor edilmiştir ( Banerjee ve ark., 2003; Kumar ve ark., 2017). Ratlarin kalp katalaz enzim aktivitesi D, DA-1, DA-2 ve DE grubunda $K$ grubuna göre anlamlı $(\mathrm{P}<0.05)$ azalma gözlendi. Gruplar arasinda ise istatiksel olarak anlamlı bir değişim olmadı (Şekil 5, Çizelge 4). Borek (2001) sarımsak ekstrelerinin kalp, böbrek ve karaciğerde katalaz aktivitesini artırdığını rapor etmiştir. İnsan eritrositleri katalaz enzimi üzerine katekolün etkisi araştırılmış katekol eritrositlerde $\mathrm{H}_{2} \mathrm{O}_{2}$ miktarını artırarak katalaz enzim düzeyini azalmıştır (Bukowska ve Kowalska, 2004). A.tuncelianum ekstraktında yüksek oranda bulunan pirokatekol, rat kalp dokusunda katalaz enzim aktivitesini azaltmış olabileceği düşünülebilir. Bu sonucun mekanizması ise şu şekilde açıklanabilir; Fenollerin hidroksil grupları güçlü temizleme kapasitelerine sahip olduklarmdan antioksidan aktiviteye yardımcı olurlar. A.tuncelianum ekstraktında yüksek miktarda bulunan ve fenollere denk olan pirokatekol (Tello ve ark., 2008), eksojen bir antioksidan olarak, antioksidan savunma sistemine yardımcı olur. ATSE verilen gruplarda katalaz enzim aktivitesinin azalması, ekstraktlar nedeniyle pirokatekol kullanımının, katalaz enzimine olan ihtiyacı azalttığına işaret olabilir. Nitekim polifenollerin günlük 1gr'ın üzerinde sebze ve meyvelerden zengin diyetlerle alınmasının mutagenez ve karsinogenezi inhibe ettikleri savunulmaktadır (Gülçin ve ark., 2004).

\section{A.tuncelianum Ekstraktının Kalp Süperoksit Dismutaz Enzim aktivitesine Etkisi}

Literatür verileri incelendiğinde, DMBA ile indüklenmiş rat dokularında SOD enzim aktivitesinin düşmesi anlamlı azalma olarak kabul edilmiştir. DMBA ile indüklenmiş ratlara verilen antioksidatif madddelerin SOD enzim aktivitesini artırmaları da anlamlı bir artış olarak ifade edilmiştir (Banerjee ve ark., 2003; Kasım, 2015) . Çalışmamızda, SOD enzim aktivitesinde; DMBA verilen tüm hasta gruplarında, kontrol grubuna göre anlaml bir azalma $(\mathrm{P}<0.05)$ gözlendi. Gruplar kendi aralarında kıyaslandığında ise; DA-1 ve DA-2 gruplarinda DE grubuyla kıyaslandığında istatiksel olarak anlamlı artma $(\mathrm{P}<0.05)$ belirlendi. Sarımsak homojenatının uygulandığı bir çalışmada Banerjee ve arkadaşları (2003) kronik sarımsak alımının izoproterenol ile indüklenmiş sıçan kalbindeki endojen antioksidan aktivite üzerine etkisine bakmışlardır. Sadece izoproterenol verilen grupta SOD aktivitesi anlaml $(\mathrm{P}<0.05)$ bir şekilde azalmıştır. İzoproterenol'e ilaveten verilen $125, \quad 250$ ve $500 \mathrm{mg} / \mathrm{kg}$ derişimlerindeki sarımsağın ise, sıçan kalbinde SOD enzim aktivitesinde anlamlı bir şekilde artmaya neden olduğunu bildirmişlerdir. Borek (2001) sarımsak ekstrelerinin kalp, böbrek ve karaciğerde SOD aktivitesini ve redükte glutatyon düzeylerini artırdığını rapor etmiştir. DMBA $+500 \mathrm{mg} / \mathrm{kg} A$. tuncelianum verilen (DA-2) grubunda DMBA (D) verilen gruba göre SOD enzim aktivitesinde anlamlı artış olmuştur $(\mathrm{P}<0.05)$. A tuncelianum ekstratının dozu artığında SOD enzim aktivitesi D grubuna göre artmıştır. Bizim sonuçlarımız diğer araştırmacıların sonuçları ile paralel bulunmuştur.

\section{A.tuncelianum Ekstraktının Kalp Total Glutatyon düzeylerine Etkisi}

Total glutatyon, glutatyon peroksidaz enzimi tarafından, peroksit radikallerini temizlemek için kullanılan bir bileşiktir. DMBA ile indüklenmiş ratlara verilen antioksidatif madddelerin, oksidatif hasar sonucu düşmüş GSH düzeylerini yükseltmeleri ise anlamlı bir artış olarak rapor edilmiştir (Banerjee ve ark., 2003; Kasım, 2015). Çalışmamızda DMBA uygulanmış ratların kalp total gulutatyon düzeylerinde DA-1 grubu ile DE grubu kıyaslandığında istatiksel olarak anlamlı $(\mathrm{P}<0.05)$ azalma belirlendi. Kalp dokusunda total glutatyon düzeyleri D, DA-1 ve DA-2 gruplarında kontrole göre 
anlamlı fark gözlenmemiştir. D grubuna göre DA-1 grubunda bir miktar artma gözlenmiştir. Sarımsak ekstreleri ile yapılan bir çalışmada, bu ekstrelerin kalp, böbrek ve karaciğerde redükte glutatyon düzeylerini artırdığını belirtilmiştir (Borek, 2001). Bu sonuçların Allium sativum için yapılan çalışma bulgularıyla paralel olduğu görülmüştür.
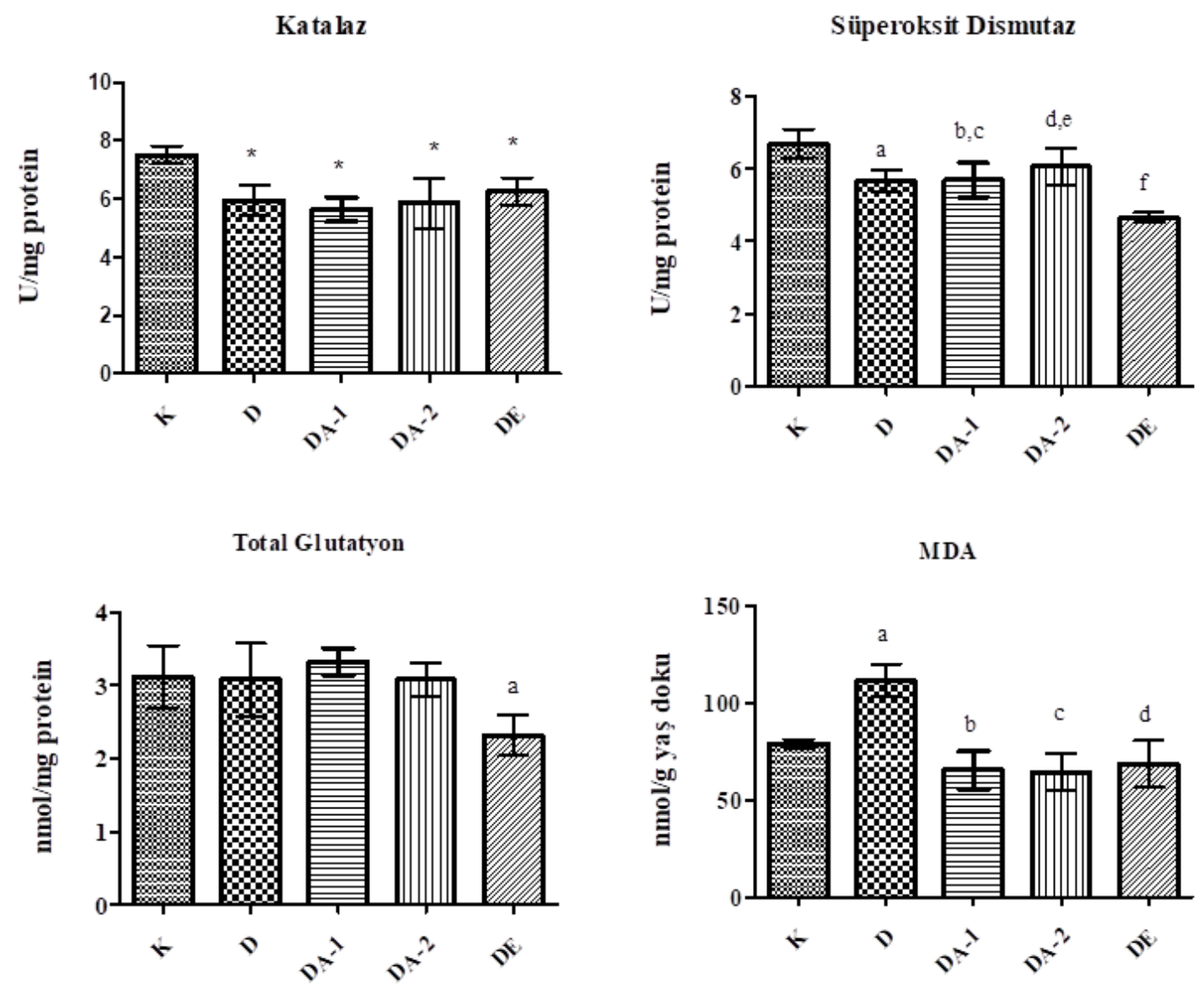

Şekil 5. Rat kalp dokusunda katalaz, Süperoksit Dismutaz enzim aktiviteleri ve Total Glutatyon, MDA düzeyleri. K: Kontrol; D: DMBA; DA-1: DMBA + $250 \mathrm{mg} / \mathrm{kg}$ A. tuncelianum DA-2: DMBA $+500 \mathrm{mg} / \mathrm{kg}$ A. tuncelianum; DE: DMBA + E Vitamini Grupları

Çizelge 4. Rat kalp doku homojenatları antioksidan enzim aktiviteleri, total GSH ve MDA düzeyleri

\begin{tabular}{|c|c|c|c|c|c|}
\hline Parametreler & $\mathrm{K}$ & $\mathrm{D}$ & $\mathrm{DA}-1$ & DA-2 & $\mathrm{DE}$ \\
\hline CAT & $7.51 \pm 0.31$ & $5.94 \pm 0.53^{*}$ & $5.64 \pm 0.41^{*}$ & $5.86 \pm 0,85^{*}$ & $6.26 \pm 0.47^{*}$ \\
\hline GSH & $3.12 \pm 0.42$ & $3.08 \pm 0.49$ & $3.32 \pm 0.18$ & $3.08 \pm 0.22$ & $2.32 \pm 0.27 \mathrm{a}$ \\
\hline SOD & $6.69 \pm 0,39$ & $5.65 \pm 0.30^{\mathrm{a}}$ & $5.69 \pm 0.48^{\mathrm{bc}}$ & $6.07 \pm 0.50^{\text {de }}$ & $4.64 \pm 0.14^{\mathrm{f}}$ \\
\hline MDA & $79.03 \pm 2.17$ & $111.74 \pm 4.30^{\mathrm{a}}$ & $64.43 \pm 9.61^{\mathrm{b}}$ & $64.23 \pm 9.54^{\mathrm{c}}$ & $68.48 \pm 12.19^{d}$ \\
\hline CAT & \multirow{3}{*}{\multicolumn{5}{|c|}{$\begin{array}{l}\text { (*) K vs D; (*) K vs DA-1; (*)K vs DA-2; (*) K vs DE }(\mathrm{P}<0.05) \\
\text { (a) } \mathrm{DA}-1 \text { vs } \mathrm{DE}(\mathrm{P}<0.05) \\
\text { (a) K vs D; (b) K vs DA-1; (c) DA1 vs DE; (d) K vs DA-2; (e) DE vs DA-2 } \\
\text { (f) K vs DE (P<0.05) }\end{array}$}} \\
\hline GSH & & & & & \\
\hline SOD & & & & & \\
\hline MDA & \multicolumn{5}{|c|}{ (a) K vs D; (b) D vs DA-1; (c) D vs DA-2; (d) D vs DE $(\mathrm{P}<0.05)$} \\
\hline
\end{tabular}

\section{A.Tuncelianum Ekstraktının Kalp Malondialdehit} düzeylerine Etkisi

Malondialdehit (MDA) serbest radikal saldırıları sonucu hücre membranında bulunan lipitlerin peroksidasyonunun son ürünüdür. DMBA ile indüklenmiş ratlarda MDA miktarının artması ve hayvanlara verilen antioksidatif madddeler ile miktarının azalması genel olarak olumlu bir sonuç olarak değerlendirilmiştir (Kasım, 2015; Küçükkurt ve ark., 2017; Wu ve ark., 2001). Şekil 5 ve çizelge 4'e göre rat kalp dokusu malondialdehit düzeyleri; D grubunda, K grubuna göre anlamalı bir artma $(\mathrm{P}<0.05)$ göstermiştir. DA-1, DA-2 ve DE gruplarında, D grubuna göre anlamlı azalma $(\mathrm{P}<0.05)$ belirlenmiştir. 
Kastamonu sarımsağı için yapılan bir çalışmada, MDA düzeylerinde; sadece DMBA verilen grupta, kontrol grubuna göre anlamlı artmanın $(\mathrm{P}<0,05)$ olduğu taze, bekletilmiş ve tablet sarımsak verilen gruplarda ise DMBA grubuna göre anlamlı azalmanın $(\mathrm{P}<0,05)$ olduğu rapor edilmiştir (Solmaz, 2011). Banerjee ve arkadaşlarının (2003) yaptığı bir çalışmada sulu sarımsak ekstraktının, tavşan karaciğer homojenatında bir lipid peroksidasyon ürünü olan malondialdehit (MDA) oluşumunu engellediği ortaya konmuştur. Bu sonuçlar bizim bulgularımızı destekler niteliktedir.

\section{SONUÇ}

Çalışma bulgularına göre $A$. tuncelianum'un su ekstrelerinin pirokatekol, Sinamik asit, Hesperidine, Kumarin, Vanilik asidi, Fumarik asit, Ferulik asit, Gallik asit ve P- Kumarik asit olmak üzere 10 çeşit fenolik bileşen içermektedir. 7,12-DMBA ile indüklenen rat kalp dokularında, kontrol grubuna kıyasla tüm parametreler istatistiksel olarak anlamlı $(\mathrm{P}<0,05)$ bir şekilde değişime uğramıştır. Değişime uğrayan bu parametreler, 250 ve $500 \mathrm{mg} / \mathrm{kg}$ vücut ağırlığı dozunda ATSE verilen gruplarda; süperoksit dismutaz enzim aktivitesinde ve total glutatyon düzeylerinde istatiksel olarak anlamlı artma $(\mathrm{P}<0,05)$ ve malondialdehit düzeylerinde ise istatiksel olarak anlamlı $\quad(\mathrm{P}<0,05) \quad$ bir azalma gözlenmiştir. Çalışmamızda katalaz enzim aktivitesinin ATSE verilen gruplarda düştüğü belirlenmiştir. Buradan da tüm enzim aktivitelerinin seviyesini anlamlı olarak artırmadığını görmek mümkündür. $\mathrm{Bu}$ sonuç şöyle yorumlanabilir; Katalaz enzim aktivitesi, oksidatif stres sonucu, stresle baş etmek üzere artar. Eğer ortamda fenolik bileşikler gibi eksojen bir antioksidan ajan varsa, oksidatif stresle mücadeleye destek olacak ve bu enzim seviyelerinin artmasina gerek kalmayacaktır. Nitekim ATSE içeriğinde pirokatekol, kainik asit, sinamik asit, fumarik asit ve gallik asit gibi fenolik bileşenlerin varlığı yapılan analizler sonucu gösterilmiştir. $\mathrm{Bu}$ yüzden de bu enzim aktivitesinin azalması anlaml ve olumlu olarak yorumlanabilir. A.tuncelianum un içerdiği fenolik bileşikler sayesinde antioksidan enzim aktivitelerini olumlu bir şekilde değiştirdiğini ve kalp dokusunu oksidatif hasara karşı, enzim aktivitelerini düzenleyerek koruyabileceğini söyleyebiliriz. Fakat kullanılacak miktar konusunun, toksik düzey çalışmalarıyla desteklenmesi gerekmektedir. Sonuç olarak $A$. tuncelianum'un lezzeti yanında, yüksek değerde yararlı kükürtlü bileşenleri ve dokular için çok önemli ve bir o kadar da toksik olabilecek bileşikler içerdiğini, antioksidan aktiviteye sahip olduğunu ve buna bağlı olarak lipit hasarını önlediğini ve böylece oksidatif hasarın neden olduğu hastalıkları önleyebileceğini söyleyebiliriz.

\section{TEŞEKKÜR}

Çalışmanın yapılmasında destek sağlayan İnönü Üniversitesi Bilimsel Araştırma Projeleri Koordinasyon Birimi'ne teşekkür ederiz (Proje No: 2013/50).

\section{KAYNAKLAR}

Akerboom TPM, Sies H 1981. Assay of Glutathione, Glutathione Disulfide, and Glutathione Mixed Disulfides in Biological Samples. Methods in Enzymology, 77(C): 373-382.

Aras A 2016. Türkiye'de Yetişen Endemik (Nepeta nuda Subsp. L.) Bitkisine Ait Farklı Ekstrelerin Antioksidan Aktivitelerinin Belirlenmesi ve Fenolik Bileşikiçeriklerinin LC-MS/MS ile Analizi. D.Ü. Fen Bil. Ens., Kimya ABD, Doktora Tezi, 129 S.

Banerjee SK, Sood S, Dinda, AK, Das TK, Maulik SK 2003. Chronic oral administration of raw garlic protects against isoproterenol-induced myocardial necrosis in rat, Comparative Biochemistry and Physiology-C. Toxicology and Pharmacology, 136(4): 377-386.

Bilici M, Efe H, Köroğlu MA, Uydu HA, Bekaroğlu M, Değer O 2001. Antioxidative enzyme activities and lipid peroxidation in major depression: alterations by antidepressant treatments. Journal of Affective Disorders, 64(1): 43-51.

Borek C 2001. Antioxidant health effects of aged garlic extract. The Journal of Nutrition, 131(3): 1010-5.

Bradford MM 1976. A rapid and sensitive method for the quantitation of microgram quantities of protein utilizing the principle of protein-dye binding. Analytical Biochemistry, 72(1-2): 248-54.

Dinis TC, Madeira VM, Almeida LM 1994. Action of phenolic derivatives (acetaminophen, salicylate, and 5-aminosalicylate) as inhibitors of membrane lipid peroxidation and as peroxyl radical scavengers. Archives of Biochemistry and Biophysics, 315(1): 161-169.

Eşrefoğlu M, Gül M, Ateş B, Batçıŏlu K, Selimoğlu MA 2006. Antioxidative effect of melatonin, ascorbic acid and $\mathrm{N}$-acetylcysteine on caeruleininduced pancreatitis and associated liver injury in rats. World Journal of Gastroenterology, 12(2): 259.

Evans C, Miller N, Paganga G 1997. Antioxidant properties of phenolic compounds. Trends in Plant Science, 2(4): 152-9.

Farag MA, Ali SE, Hodaya RH, El-Seedi HR, Sultani HN, Laub A, Eissa TF, Abou-Zaid FO, Fratianni F, Ombra MN, Cozzolino A, Riccardi R, Spigno P, Tremonte P, Coppola R, Nazzaro F 2016. Phenolic constituents, antioxidant, antimicrobial and antiproliferative activities of different endemic Italian varieties of garlic (A. sativum L.). Journal of Functional Foods, 21: 240-8.

Geleijnse JM, Launer LJ, Hofman A, Pols HA, 
Witteman JC 1999. Tea flavonoids may protect against atherosclerosis: the Rotterdam Study. Archives of Internal Medicine, 159(18): 2170-4.

Gülçin I, Küfrevioğlu Öİ, Oktay M, Büyükokuroğlu ME 2004. Antioxidant, antimicrobial, antiulcer and analgesic activities of nettle (Urtica dioica L.). Journal of Ethnopharmacology, 90(2-3): 205-15.

Halliwell B, Chirico S 1993. Lipid peroxidation: its mechanism, measurement, and significance. The American Journal of Clinical Nutrition, 57(5): 71524.

Işık M, Korkmaz M, Bursal E, Gulcin I, Koksal E, Tohma H 2015. Determination of antioxidant properties of Gypsophila bitlisensis bark. International Journal of Pharmacology, 11(4): 36671.

İzol E 2016. Bazı Allium (Yabani Sarımsak) Türlerinin Aflatoksin, Ağır Metal ve Sekonder Metabolit İçeriklerinin ICP-MS ve LC-MS/MS İle Belirlenmesi ve Biyolojik Aktivitelerinin İncelenmesi. D.Ü. Fen Bil. Ens., Kimya ABD, Yüksek Lisans Tezi, $129 \mathrm{~s}$.

Karaoğul E, Kirecci E, Alma MH 2016. Determination of phenolic compounds from Turkish kermes oak (Quercus coccifera L.) roots by high performance liquid chromatography; its antimicrobial activities. Feb-Fresenius Environmental Bulletin, 25(7): 2356-2363.

Köksal E, Tohma H, Kılıç Ö, Alan Y, Aras A, Gülçin İ, Bursal E 2017. Assessment of antimicrobial and antioxidant activities of Nepeta trachonitica: analysis of its phenolic compounds using HPLCMS/MS. Scientia Pharmaceutica, 85(2): 1-14.

Kumar VM, Henley AK, Nelson CJ, Indumati O, Rao YP, Rajanna S, Rajanna B 2017. Protective effect of Allium sativum (garlic) aqueous extract against lead-induced oxidative stress in the rat brain, liver, and kidney. Environmental Science and Pollution Research, 24(2):1544-52.

Küçükkurt İ, Acaröz DA, Demirel HH, Sinan IN, Eryavuz A 2017. Ratlarda Gentamisin İle İndüklenmiş Oksidatif Streste Borun Muhtemel Koruyucu Etkisinin Dokularda Araştırılması. Kocatepe Veteriner Dergisi, 10(3):172-9.

Landis GN, Tower J 2005. Superoxide dismutase evolution and life span regulation. Mechanisms of Ageing and Development, 126(3):365-79.

Martins N, Petropoulos S, Ferreira IC 2016. Chemical composition and bioactive compounds of garlic
(Allium sativum L.) as affected by pre-and postharvest conditions: A review. Food Chemistry, 211(3):41-50.

Pandey M, Debnath M, Gupta S, Chikara SK 2011. Phytomedicine: An ancient approach turning into future potential source of therapeutics. Journal of Pharmacognosy and Phytotherapy, 3(1):113-7.

Solmaz, FÖK 2011. 7,12-DMBA ile İndüklenen Rat Karaciğer Dokusunda Çeşitli Sarimsak Ekstrelerinin Koruyucu Etkilerinin İncelenmesi. İ.Ü. Sağ. Bil. Ens., Biyokimya ABD, Bitirme Tezi, $113 \mathrm{~s}$.

Takım K 2015. Tunceli Dağ Sarımsağı'nın (Allium tuncelianum) in vitro Antioksidan Kapasitesinin Ölçülmesi, Ratlarda Antioksidan Enzim Aktiviteleri Üzerine Etkisi Ve Antikanser Özelliğinin Belirlenmesi. İ.Ü. Fen Bil. Ens., Kimya ABD, Doktora Tezi, $113 \mathrm{~s}$.

Tello S, Halifeoğlu İ, Bozkurt M, Bulmuş Ö 2008. Meme Kanseri Oluşturulmuş Ratlarda Isırgan Otunun Total Antioksidan Durumu Üzerine Etkisi. Fırat Üniversitesi Sağlık Bilimleri Tıp Dergisi. 22 : 179-83.

Vlase L, Parvu M, Parvu EA, Toiu A 2012. Chemical constituents of three Allium species from Romania. Molecules, 18(1):114-27.

Vardi N, Parlakpinar H, Ozturk F, Ates B, Gul M, Cetin A, Erdogan A, Otlu A 2008. Potent protective effect of apricot and B-carotene on methotrexateinduced intestinal oxidative damage in rats. Food and Chemical Toxicology, 46(9): 3015-22.

Yılmaz MA 2015. Bazı Achillea türlerinin LCMSIT/TOF ve LC-MS/MS ile metabolik profillerinin çıkarılması ve biyolojik activitelerinin belirlenmesi. D.Ü. Fen Bil. Ens., Kimya ABD, Doktora Tezi, 314 s.

Yünlü S 2011. Soğan (Allium cepa) Ve Sarımsaktaki (Allium sativum) Fenolik Bileşiklerin HPLC Yöntemiyle Tayin Edilmesi. S.D.Ü. Fen Bil. Ens., Kimya ABD, Yüksek Lisans Tezi, $101 \mathrm{~s}$.

Wessjohann LA 2017. Phytochemical profiles and antimicrobial activities of $A$. cepa red cv. and $A$. sativum subjected to different drying methods: a comparative MS-based metabolomics. Molecules, 22(5): 761.

Wu CC, Sheen LY, Chen HW, Tsai SJ, Lii CK 2001. Effects of organosulfur compounds from garlic oil on the antioxidation system in rat liver and red blood cells. Food and Chemical Toxicology, 39(6):563-9 